Anna Budnik

Uniwersytet w Biatymstoku

Marta J. Czubkowska

Wojewódzki Sąd Administracyjny w Biatymstoku

\title{
ROLA KOMISARZA WYBORCZEGO W PODZIALE GMINY NA OKREGGI WYBORCZE
}

\section{Wstęp}

Wybory samorządowe są przejawem niezależności samorządu terytorialnego od władzy państwowej i za ich organizację odpowiedzialne są organy tego samorządu. Organem wyborczym sprawującym nadzór nad prawidłowym przebiegiem wyborów lokalnych jest zaś komisarz wyborczy, który posiada szereg kompetencji w związku z pełnioną przez siebie funkcją.

Jedną z nich jest przyznana na mocy art. $17 \S 2$ Kodeksu wyborczego ${ }^{1}$ kompetencja komisarza wyborczego do wydania postanowienia o utworzeniu okręgów wyborczych w wyborach do rad gmin w przypadku, gdy po bezskutecznym wezwaniu rady gminy do wykonania zadań zgodnie z prawem rada nie uczyniła tego $\mathrm{w}$ terminie lub gdy jej uchwała o utworzeniu okręgów wyborczych jest niezgodna z prawem. Kodeks wyborczy ponadto na mocy art. 420 uregulował odmiennie niż przewiduje to art. 101 ustawy o samorządzie gminnym ${ }^{2}$ możliwość zaskarżenia uchwały rady gminy o utworzeniu okręgów wyborczych przez wyborców. Wskazane przepisy budzą wątpliwości co do ich zgodności z Konstytucją, na co zwrócił uwagę również Naczelny Sąd Administracyjny, który skierował do Trybunału Konstytucyjnego pytanie prawne o zbadanie ich zgodności z Konstytucją RP. ${ }^{3}$

Przedmiotem niniejszego artykułu jest analiza roli komisarza wyborczego w procesie tworzenia okręgów wyborczych do rady gminy. Została w nim przed-

1 Ustawa z dnia 5 stycznia 2011 r. - Kodeks wyborczy (Dz.U. z 2011 r. Nr 21, poz. 112 z późn. zm.), dalej powoływana jako k.w.

2 Ustawa z dnia 8 marca 1990 r. o samorządzie gminnym (tekst jedn. Dz.U. z 2011 r. poz. 594), dalej powoływana jako u.s.g.

3 Pytanie prawne NSA z dnia 10 grudnia 2013 r. dostępne na stronie TK: http://trybunal.gov.pl/rozprawy/komunikaty-prasowe/komunikaty-po/art/7095-podzial-gminy-na-okregi-wyborcze-odwolanie-od-orzeczenia-panstwowej-komisji-wyborczej/s/p-514/; P 5/14 (data dostępu: 15.12.2014 r.). 
stawiona ewolucja pozycji ustrojowej komisarza wyborczego z uwzględnieniem zadań w odniesieniu do tworzenia okręgów wyborczych przez gminę. Przedmiotem rozważań uczyniono charakter prawny uchwały rady gminy o utworzeniu okręgów wyborczych oraz postanowienia zastępczego wydawanego przez komisarza wyborczego. Ponadto w artykule omówiono problem nadzoru wojewody i kontroli legalności uchwały rady gminy o utworzeniu okręgów wyborczych do rad gmin.

Celem artykułu jest wykazanie, że kompetencja komisarza do wydania postanowienia zastępczego narusza art. 87 ust. 2 Konstytucji RP, ponieważ przyznaje mu prawo do stanowienia prawa miejscowego, a brak możliwości wniesienia skargi do sądu administracyjnego na uchwałę o utworzeniu okręgów wyborczych na mocy art. 101 u.s.g. odbiera wyborcom prawo do sądu przysługujące na podstawie art. 45 ust. 1 Konstytucji RP. Ponadto brak środka prawnego od postanowienia zastępczego narusza samodzielność gminy oraz pozbawia ją sądowej ochrony zagwarantowanej przez art. 165 ust. 2 Konstytucji RP.

\section{Podział gminy na okręgi wyborcze przez komisarza wyborczego - rys historyczny}

Podział gminy na okręgi wyborcze stanowi szczególną kompetencję komisarza wyborczego. W okresie prawie ćwierć wieku funkcjonowania instytucji komisarza wyborczego kompetencja ta nie była uregulowana w sposób jednorodny.

Pierwotnie w Ordynacji wyborczej do $\mathrm{rad}_{\mathrm{gmin}}{ }^{4}$ kompetencja ta została przyznana bezpośrednio komisarzowi wyborczemu. Wojewódzki komisarz wyborczy był uprawniony, na wniosek właściwego zarządu gminy (miasta), do ustalenia odrębnie dla każdej rady granic i numerów okręgów jednomandatowych bądź liczby okręgów wielomandatowych, ich granic i numerów oraz liczby radnych wybieranych w każdym okręgu. Zarządzenie wojewódzkiego komisarza wyborczego ustalające okręgi wyborcze ogłaszało się w wojewódzkim dzienniku urzędowym oraz podawało do wiadomości wyborców przez rozplakatowanie obwieszczeń najpóźniej w 45. dniu przed dniem wyborów. W obwieszczeniach tych wymieniało się również siedzibę właściwej terytorialnej komisji wyborczej (art. 14 ust. 1 i 2). W Ordynacji wyborczej do rad gmin w art. 25 ust. 2 pkt 3 wprost do zadań wojewódzkiego komisarza wyborczego zaliczono tworzenie okręgów wyborczych.

W Ordynacji wyborczej z dnia 16 lipca 1998 r. ${ }^{5}$ początkowo kompetencja komisarza wyborczego w tym zakresie nie została uregulowana. Dopiero przez art. 4 pkt 52 ustawy zmieniającej z dnia 15 lutego 2002 r. dodano do niej przepis art. 203a. ${ }^{6}$

Ustawa z dnia 8 marca 1990 r. (Dz.U. z 1990 r. Nr 16, poz. 96).

Dz.U. Nr 95, poz. 602.

Art. 203a ust. 1 stanowi:, „Jeżeli właściwe organy gminy nie wykonują w terminie, w sposób zgodny z prawem, zadań dotyczących utworzenia obwodów głosowania, powołania obwodowych komisji wyborczych, sporządzenia spisów wyborców lub podziału gminy na okręgi wyborcze, właściwy miejscowo komisarz wyborczy wzywa 
Regulacja ta nie upoważniała komisarza ani do samodzielnego podziału gminy na okręgi wyborcze, ani do wydawania rozstrzygnięć zastępczych. Upoważniała go jedynie do wezwania odpowiednich organów gmin do wykonania zadań w zakresie podziału gminy na okręgi wyborcze w sposób zgodny z prawem w wyznaczonym terminie, a w razie bezskutecznego upływu terminu - do wystąpienia do wojewody o zastępcze ich wykonanie.

Treść przepisu art. 203a została zmieniona przez art. 1 pkt 67 ustawy z dnia 20 kwietnia 2004 r. $^{7}$ zmieniającej Ordynację z dniem przystąpienia Rzeczypospolitej Polskiej do Unii Europejskiej. Nowa treść tego przepisu upoważniła komisarza wyborczego po pierwsze do wezwania organów jednostki samorządu terytorialnego do wykonania w terminie, w sposób zgodny z prawem, zadań dotyczących podziału gminy na okręgi wyborcze, po drugie do zastępczego podziału gminy na okręgi wyborcze w razie bezskutecznego upływu terminu. Po niezwłocznym wykonaniu tego zadania komisarz wyborczy został zobligowany do powiadomienia o tym Państwowej Komisji Wyborczej.

W aktualnie obowiązującym prawie wyborczym właściwie in extenso powielono w art. 17 ust. 2 k.w. powyższe rozwiązanie. ${ }^{8}$ Zgodnie z art. $167 \S 3$ k.w., komisarz wyborczy w zakresie swoich ustawowych uprawnień wydaje postanowienia, co oznacza, że wykonanie kompetencji w zakresie podziału gminy na okręgi wyborcze wymaga wydania przez komisarza właśnie takiego aktu. Nadto w k.w. komisarz wyborczy uzyskał prawo weryfikacji uchwał rad gmin w sprawach okręgów wyborczych w trybie art. $420 \S 1$ i 2 k.w.

\section{Charakter prawny uchwały rady gminy o podziale gminy na okręgi wyborcze}

Uchwała rady gminy o utworzeniu okręgów wyborczych ma istotne znaczenie dla ukształtowania całego procesu wyborczego, ponieważ służy temu, aby mandaty do rady gminy były korzystnie obsadzone ze względu na miejsce zamieszkania wyborców. Dlatego też zasadą w tworzeniu okręgów wyborczych do rad gmin jest to,

te organy do wykonania zadań w sposób zgodny z prawem w wyznaczonym terminie, a w razie bezskutecznego upływu terminu występuje do wojewody o zastępcze ich wykonanie".

7 (Dz.U. z 2004 r. Nr 102, poz. 1055); Art. 203a ust. 1 stanowi: „Jeżeli właściwe organy nie wykonują w terminie, w sposób zgodny z prawem zadań dotyczących utworzenia obwodów głosowania, powołania obwodowych komisji wyborczych, sporządzenia spisów wyborców lub podziału gminy na okręgi wyborcze, właściwy komisarz wyborczy wzywa te organy do wykonania zadań w sposób zgodny z prawem w wyznaczonym terminie, a w razie bezskutecznego upływu terminu niezwłocznie wykonuje te zadania i powiadamia o tym Państwową Komisję Wyborczą".

$8 \quad$ Art. 17 § 1 stanowi, że „Jeżeli właściwe organy gminy nie wykonują w terminie lub w sposób zgodny z prawem, zadań dotyczących utworzenia obwodów głosowania lub ich zmiany, powołania lub zmian w składach komisji obwodowych, właściwy komisarz wyborczy wzywa te organy do wykonania zadań w sposób zgodny z prawem w wyznaczonym terminie, a w razie bezskutecznego upływu terminu niezwłocznie wykonuje te zadania i powiadamia o tym Państwową Komisję Wyborczą”, zaś art. 17 § 2: „Przepis § 1 stosuje się odpowiednio, jeżeli właściwy organ nie dokonał podziału gminy, powiatu lub województwa na okręgi wyborcze w terminie lub w sposób zgodny z prawem". 
aby podział gminy na okręgi odbywał się według jednolitej normy przedstawicielstwa obliczonej przez podzielenie liczby mieszkańców gminy przez liczbę radnych wybieranych do danej rady (art. $419 \S 2$ k.w.). Podział gminy na okręgi wyborcze jest stały (art. $419 \S 1$ k.w.). Wojewódzki Sąd Administracyjny w Poznaniu w wyroku z dnia 22 września 2009 r. stwierdził, że „Gwarancja trwałości dokonanych podziałów na okręgi wyborcze ma olbrzymie znaczenie dla zapewnienia demokratycznego charakteru postępowania wyborczego. [...] Istotą omawianej regulacji jest zapewnienie trwałości raz wytyczonych okręgów wyborczych i dlatego przeprowadzenie ewentualnych zmian w podziale gminy na okręgi zostało ściśle uregulowane przez ustawodawcę i poddane silnej kontroli (wojewody i komisarza wyborczego)". ${ }^{9}$

Uchwała rady gminy o utworzeniu okręgów wyborczych do rady gminy jest aktem prawa miejscowego. W myśl art. 87 ust. 2 Konstytucji RP „Źródłami powszechnie obowiązującego prawa Rzeczypospolitej Polskiej są na obszarze działania organów, które je ustanowiły, akty prawa miejscowego". Tworzenie tego prawa jest zaś przejawem samodzielności jednostek samorządu terytorialnego (jst).

Podjęcie uchwały o podziale gminy na okręgi wyborcze to wyraz samodzielności gminy, ponieważ organizacja i przeprowadzenie wyborów lokalnych, w tym podział gminy na okręgi jest zadaniem własnym gminy. Zadanie to nie mieści się w kategorii ani zadań zleconych z zakresu administracji rządowej, ani też nie wiąże się z obowiązkiem z zakresu przygotowań i przeprowadzenia wyborów powszechnych oraz referendów, o których stanowi art. 8 u.s.g. Utworzenie okręgów wyborczych do rady gminy jest realizacją zadań własnych tej jednostki. Zdaniem P. Dobosza „[...] przeprowadzenie wyborów powszechnych oraz referendów ze swej istoty mają charakter niesamorządowy, obcy dla samorządu terytorialnego w tym znaczeniu, iż nie stanowią kategorii tzw. zadań własnych. Trudno jest je także uznać za zadania rządowe, po pierwsze, z tego powodu, że są wymienione obok zadań z zakresu administracji rządowej, a gdyby nimi były, to nie istniałaby potrzeba ich odrębnego wyszczególnienia, a po drugie z tej przyczyny, że są to raczej kategorie zadań ogólnopaństwowych". ${ }^{10}$ Zdaniem T. Molla „,potwierdzeniem wyżej przytoczonej tezy zdaje się być rozwiązanie przyjęte $\mathrm{w}$ art. 4 a ustawy o samorządzie powiatowym ${ }^{11}$ oraz $\mathrm{w}$ art. 14 ust. 3 ustawy o samorządzie województwa, ${ }^{12}$ gdzie zadania $\mathrm{z}$ zakresu organizacji przygotowań i przeprowadzenia wyborów powszechnych oraz referendów są wyraźnie wyodrębnione od innych zadań tych jednostek samorządu terytorialnego. Dodać należy, że nie całość problematyki wyborczej zostaje zlecona gminie. Nie jest zlecona gminie w tym zakresie, w którym wiąże się z wyborami samorządowymi". ${ }^{13}$

9 II SA/Po 350/09, dostępny na stronie: www.orzeczenia.nsa.gov.pl (data dostępu: 15.12.2014 r.).

10 P. Dobosz, (w:) K. Bandarzewski, P. Chmielnicki, P. Dobosz, W. Kisiel, P. Pryczko, M. Mączyński (red.), Komentarz do ustawy o samorządzie gminnym, Warszawa 2004, s. 135.

Ustawa z dnia 5 czerwca 1998 r. o samorządzie powiatowym (tekst jedn. Dz.U. z 2013 r. poz. 595 z późn. zm.).

Ustawa z dnia 5 czerwca 1998 r. o samorządzie województwa (tekst jedn. Dz.U. z 2013 r. poz. 596 z późn. zm.).

T. Moll, (w:) B. Dolnicki (red.), Ustawa o samorządzie gminnym. Komentarz, Warszawa 2010, s. 147. 
Uchwała rady gminy o podziale tej jednostki na okręgi wyborcze jest aktem prawa miejscowego, ponieważ odpowiada warunkom, których spełnienie jest konieczne do tego, aby dany akt mógł być uznany za powszechnie obowiązujące źródło prawa lokalnego. Po pierwsze, akt prawa miejscowego jest aktem podustawowym i ma w stosunku do ustawy charakter wykonawczy. Szczegółowa procedura tworzenia okręgów wyborczych w wyborach lokalnych przewidziana jest w Dziale VII, rozdziale 10 k.w. Upoważnienie do podjęcia uchwały o utworzeniu okręgów wyborczych zawarte jest w art. $419 \S 1$ k.w. W myśl tego przepisu „Podział na okręgi wyborcze, ich granice i numery oraz liczbę radnych wybieranych w każdym okręgu ustala, na wniosek wójta, rada gminy według jednolitej normy przedstawicielstwa obliczonej przez podzielenie liczby mieszkańców gminy przez liczbę radnych wybieranych do danej rady [...]".

Akty prawa miejscowego muszą mieć charakter normatywny, tzn. zawierać normy generalne i abstrakcyjne. Mają one powszechny charakter, czyli obowiązują w stosunku do ogólnie określonych adresatów i są skierowane do adresatów zewnętrznych. Uchwały będące aktem prawa miejscowego są prawem dla wszystkich, którzy znajdują się w przewidzianej przez nie sytuacji. ${ }^{14}$

Oprócz wspomnianych cech, akty prawa miejscowego charakteryzują się również tym, że najczęściej bezpośrednio określają zasady zachowania się określonych kategorii adresatów, a więc ich prawa i obowiązki. Są powtarzalne, nie mogą konsumować się przez jednorazowe zastosowanie; są zabezpieczone możliwością zastosowania sankcji. ${ }^{15}$ Uchwała rady gminy o podziale na okręgi wyborcze gminy spełnia powyższe kryteria, ponieważ zawiera normy generalne i abstrakcyjne, a jej adresatami są wyborcy danej gminy. Jak podkreślił NSA w wyroku z dnia 24 lutego 2010 r., „Wyborcy ci nie są określeni imiennie, lecz ogólnie, tj. każdy mieszkaniec gminy chcący skorzystać ze swego czynnego prawa wyborczego musi się dostosować do ustaleń zawartych w takiej uchwale. Abstrakcyjność dyrektywy powinnego postępowania potwierdzana jest wykorzystywaniem tych samych obwodów dla przeprowadzenia kolejnych wyborów. Ustalenia zawarte w uchwale są prawnie sankcjonowane w szczególności przez przepisy gwarantujące prawidłowość procesu głosowania i obliczenia wyników wyborów". ${ }^{16}$

Warunkiem obowiązywania aktu prawa miejscowego jest jego ogłoszenie w wojewódzkim dzienniku urzędowym. Zgodnie z art. 419 § 2 k.w. uchwała rady gminy w sprawie okręgów wyborczych jest ogłaszana w wojewódzkim dzienniku urzędowym oraz podaje się ją do publicznej wiadomości w sposób zwyczajowo przyjęty. Ponadto po jednym egzemplarzu uchwały przekazuje się niezwłocznie wojewodzie i komisarzowi wyborczemu. Uchwała o podziale gminy na okręgi wybor-

\footnotetext{
14 Szerzej na temat cech aktów prawa miejscowego: D. Dąbek, Sądowa kontrola aktów prawa miejscowego - aspekt materialno-prawny, „Zeszyty Naukowe Sądownictwa Administracyjnego” 2013, nr 3, s. 76-103. D. Dąbek, Prawo miejscowe, Warszawa 2007, s. 31. II OSK 2001/09, dostępny na stronie: www.orzeczenia.nsa.gov.pl (data dostępu: 15.12.2014 r.).
} 
cze wchodzi w życie w ciągu 14 dni od dnia ogłoszenia, w myśl art. 4 ust. 1 ustawy z dnia 20 lipca 2000 r. o ogłaszaniu aktów normatywnych i niektórych innych aktów prawnych. ${ }^{17}$

Biorąc pod uwagę powyższe należy stwierdzić, że uchwała rady gminy w sprawie okręgów wyborczych jest aktem prawa miejscowego. Zaliczenie uchwały rady gminy do prawa miejscowego pociąga za sobą kolejne konsekwencje. Tylko bowiem akty prawa miejscowego uchwalonego przez organy gminy, powiatu oraz samorządowego województwa podlegają nadzorowi wojewody oraz kontroli sprawowanej przez sądy administracyjne.

Tym samym akty normatywne wydawane przez podmioty znajdujące się w strukturze samorządu terytorialnego, ale niebędące organami wymienionymi w ustawach ustrojowych samorządu terytorialnego nie podlegają nadzorowi organów administracji rządowej, ani kontroli sądowej..$^{18}$ Dotyczy to przede wszystkim aktów kierowników jednostek organizacyjnych samorządu terytorialnego, ale również podmiotów niewchodzących do struktury samorządu terytorialnego, np. komisarza wyborczego. Co do zasady akty te nie są zaliczane do konstytucyjnych źródeł prawa powszechnie obowiązującego i z tego punktu widzenia nie przysługuje na nie skarga do sądu administracyjnego. ${ }^{19}$

Słusznie zatem zauważył NSA, że „,...] o ile powierzenie w art. 419 § 2 Kodeksu wyborczego kompetencji radzie gminy do stanowienia prawa miejscowego pozostaje w zgodzie z art. 94 i art. 87 ust. 2 Konstytucji Rzeczypospolitej Polskiej [...], to powierzenie tej kompetencji komisarzowi wyborczemu w przepisie art. 17 $\S 1$ i 2 w zw. z art. 420 § 1 Kodeksu wyborczego narusza te przepisy. Komisarz wyborczy [...] nie jest organem pozostającym w strukturze samorządowej. Stanowi on niewątpliwie część struktury administracji wyborczej, lecz zakres jego kompetencji, jak i pozycja ustrojowa nie pozwalają, by mógł on zastępować organ stanowiący samorządu terytorialnego". ${ }^{20}$

Wydaje się, że postanowienie zastępcze komisarza wyborczego należy zaliczyć do prawa lokalnego, ponieważ zastępuje akt prawa miejscowego w ścisłym znaczeniu. Jedynie ustawodawca działając w sprzeczności z art. 87 ust. 2 Konstytucji RP powierzył stanowienie tego prawa niewłaściwemu organowi - organowi wyborczemu.

Ustawodawca ponadto przyjął, że skoro postanowienie zastępcze nie jest wydawane przez organ samorządu, to nie powinno ono również podlegać ogłoszeniu w wojewódzkim dzienniku urzędowym. Ustawa o ogłaszaniu aktów normatywnych

Tekst jedn. Dz.U. z 2011 r. Nr 197, poz. 1172 z późn. zm.

M. Brzeski, Problemy kontroli sądowoadministracyjnej działalności prawotwórczej podmiotów samorządu terytorialnego niebędących organami tego samorządu, (w:) B. Dolnicki, J.P. Tarno (red.), Samorząd terytorialny w Polsce a sądowa kontrola administracji, Warszawa 2012, s. 39.

Ibidem, s. 40

Zob. przyp. 3. 
i innych aktów prawnych oraz Kodeks wyborczy nie przewidują bowiem ogłoszenia postanowienia zastępczego w wojewódzkim dzienniku urzędowym.

Wątpliwości budzi jednak utożsamianie przez NSA postanowienia komisarza wyborczego wydawanego na podstawie art. $17 \mathrm{k} . \mathrm{w} . \mathrm{z}$ postanowieniem wydanym w trybie art. $420 \S 2$ k.w. Przepis ten w przeciwieństwie do art. 17 k.w. nie stanowi, aby komisarz wyborczy miał wydawać je w celu zastąpienia uchwały rady gminy, a jedynie reguluje skargę wyborców do komisarza wyborczego na ustalenia rady gminy w sprawach okręgów wyborczych, którą komisarz rozpatruje wydając postanowienie. Przepis ten nie odsyła do odpowiedniego stosowania przepisu art. 17 $\S 2$ k.w., ani nie wypowiada się o charakterze prawnym tego postanowienia: czy jest to postanowienie zastępcze, czy też postanowienie rozstrzygające jedynie o zgodności lub niezgodności uchwały z prawem.

Rozważania o charakterze prawnym postanowienia zastępczego nie ograniczają się jedynie do problemu, czy jest ono aktem prawa miejscowego. Kompetencja do wydania postanowienia w trybie art. $17 \S 2 \mathrm{k}$.w. wskazuje również na swoiste kompetencje nadzorcze komisarza nad działalnością rady gminy. Ten problem został przedstawiony w kolejnej części artykułu.

\section{Komisarz wyborczy jako swoisty organ nadzoru}

Jak wspomniano we wstępie, samodzielność samorządu terytorialnego jest zasadą ustrojową zagwarantowaną w art. 16 ust. 2 oraz art. 165 Konstytucji RP. Ponadto również ustawy regulujące ustrój samorządu terytorialnego wszystkich szczebli stanowią, że gmina, powiat oraz samorządowe województwo wykonują zadania publiczne we własnym imieniu i na własną odpowiedzialność, a samodzielność ta podlega ochronie sądowej. ${ }^{21}$

W literaturze przedmiotu podkreśla się, że ,,[..] istota samodzielności jednostki samorządu terytorialnego polega na tym, iż w ramach obowiązującego porządku prawnego gmina (powiat, województwo) we własnym zakresie, bez dyktatu zewnętrznego i odgórnych poleceń, decyduje o wszystkich sprawach lokalnych (regionalnych), przeznaczeniu mienia komunalnego, zasadach korzystania z obiektów publicznych, zagospodarowaniu przestrzennym, zakresie podejmowanych inwestycji, kolejności, sposobach i środkach ich realizacji, a także o związanych z tym nakładach finansowych i rzeczowych", ${ }^{22}$

Samodzielność samorządu terytorialnego nie jest jednak zasadą bezwzględną i jej granice są wyznaczone kryteriami nadzoru nad jst. Konstytucja RP wyraźnie jednak zastrzega, że jedynym kryterium nadzoru nad jst jest legalność (art. 171 ust. 1), a także w sposób wyczerpujący wymienia organy nadzoru. W myśl art. 171

21 Zob. art. 2 u.s.g., art. 2 u.s.p. oraz art. 6 u.s.w.

22 J. Jagoda, Sądowa ochrona samodzielności jednostek samorządu terytorialnego, Warszawa 2011, s. 21-22. 
ust. 2 Konstytucji są nimi Prezes Rady Ministrów i wojewoda, a w zakresie spraw finansowych regionalne izby obrachunkowe. Poza tym ustawy regulujące kompetencje organów nadzoru powinny wyraźnie regulować środki nadzoru i konsekwencje ich zastosowania.

Sądowa ochrona samorządu terytorialnego, o której będzie mowa w dalszej części artykułu, jest sprawowana przez sądy powszechne, Trybunał Konstytucyjny, ale przede wszystkim przez sądy administracyjne, które w ramach swojej właściwości rzeczowej w myśl art. $3 \S 2$ pkt 7 p.p.s.a. rozstrzygają w sprawach skarg na akty nadzoru nad działalnością samorządu terytorialnego.

W tym kontekście zasadnym jest pytanie o pozycję ustrojową komisarza wyborczego, który chociaż nie został zaliczony przez Konstytucję RP do organów nadzoru, to w procedurze tworzenia okręgów wyborczych wypełnia podobne do niego funkcje. Ustawodawca przyznał mu bowiem na podstawie art. $17 \S 2$ k.w. kompetencje do zbadania zgodności z prawem uchwały rady gminy o podziale gminy na okręgi wyborcze, a w przypadku stwierdzenia naruszenia prawa lub bezczynności rady gminy, do wydania postanowienia zastępczego w tym przedmiocie. Takie usytuowanie komisarza wyborczego wobec organów gminy, a zwłaszcza jego władcze ingerowanie $\mathrm{w}$ działanie samorządu gminnego może budzić poważne wątpliwości z punktu widzenia zgodności z Konstytucją RP.

Naczelny Sąd Administracyjny w pytaniu prawnym do Trybunału Konstytucyjnego zauważył, że „Komisarz wyborczy nie jest organem nadzoru i nie może wkraczać w sferę samodzielności jednostki samorządu terytorialnego". Tym samym wydawanego przez niego postanowienia zastępczego nie można zaliczyć do aktów nadzoru nad stanowieniem prawa miejscowego przez organy samorządu terytorialnego.

Należy jednak stwierdzić, że ustawodawca przyznając komisarzowi kompetencję do wydania postanowienia zastępczego przyznał mu swoisty środek nadzoru. W przypadku wydania postanowienia zastępczego w sytuacji, gdy rada gminy podjęła uchwałę o podziale gminy na okręgi, ale komisarz stwierdził jej niezgodność $\mathrm{z}$ prawem, działanie komisarza przypomina środek nadzoru wojewody w postaci stwierdzenia nieważności uchwały w przypadku jej niezgodności z prawem na podstawie art. 91 u.s.g. z tą jednak różnicą, że stwierdzenie nieważności ma charakter kasacyjny i jego skutkiem jest wyeliminowanie z obrotu prawnego generalnego aktu prawnego. Komisarz wyborczy nie posiada kompetencji do stwierdzenia nieważności uchwały o podziale gminy na okręgi wyborcze.

Uchwała o podziale gminy na okręgi podlega jednocześnie nadzorowi wojewody w trybie właściwym dla wszystkich aktów prawa miejscowego na podstawie art. 91 u.s.g. oraz „nadzorowi” komisarza wyborczego w trybie art. $17 \S 2$ k.w. Obowiązujące prawo dopuszcza zatem sytuację, gdzie w obrocie prawnym mogą znajdować się dwa akty prawne o odmiennej treści - uchwała rady gminy o utworzeniu 
okręgów wyborczych i postanowienie zastępcze komisarza wyborczego, co może stanowić poważny problem w przypadku ich stosowania.

$\mathrm{Z}$ drugiej strony postanowienie zastępcze komisarza przypomina swoim charakterem prawnym zarządzenia zastępcze wojewody wydawane w przypadkach przewidzianych prawem. Obecnie wojewoda wydaje zarządzenie zastępcze w sytuacji bezczynności rady gminy o podjęciu uchwały o wygaśnięciu mandatu radnego lub odwołania ze stanowiska osób wskazanych w art. 98a u.s.g ${ }^{23}$ oraz na podstawie art. 12 ust. 3 ustawy z dnia 27 marca 2003 r. o planowaniu i zagospodarowaniu przestrzennym, ${ }^{24}$ czyli w sytuacji, gdy rada gminy nie uchwaliła studium uwarunkowań i kierunków zagospodarowania przestrzennego gminy, nie przystąpiła do jego zmiany albo uchwalając takie studium, nie określiła w nim obszarów rozmieszczenia inwestycji celu publicznego o znaczeniu krajowym i wojewódzkim, wojewoda, po podjęciu czynności zmierzających do uzgodnienia terminu realizacji tych inwestycji i warunków wprowadzenia tych inwestycji do studium, wzywa radę gminy do uchwalenia studium lub jego zmiany w wyznaczonym terminie; po jego bezskutecznym upływie wojewoda sporządza miejscowy plan zagospodarowania przestrzennego albo jego zmianę dla obszaru, którego dotyczy zaniechanie gminy, w zakresie koniecznym dla możliwości realizacji inwestycji celu publicznego oraz wydaje w tej sprawie zarządzenie zastępcze. Ustawa o planowaniu i zagospodarowaniu przestrzennym stanowi, że przyjęty w tym trybie plan wywołuje skutki prawne, takie jak miejscowy plan zagospodarowania przestrzennego.

W literaturze podkreśla się, że zarządzenie zastępcze wojewody jest szczególnym aktem nadzoru, odmiennym zwłaszcza wobec rozstrzygnięć nadzorczych, które usuwają z obrotu prawnego uchwałę czy zarządzenie podjęte przez organ gminy, ale $\mathrm{w}$ to miejsce nie wprowadzają nowych aktów (zastępujących usunięte), co daje asumpt do przypisywania im „kasacyjnego” charakteru. ${ }^{25}$ Natomiast istota zarządzenia zastępczego wojewody polega na tym, że zastępuje ono, w przypadku bezczynności organu gminy, stosowny akt, jaki organ ten powinien podjąć. ${ }^{26}$

Postanowienie zastępcze komisarza wyborczego jest wydawane jednak nie tylko w przypadku bezczynności gminy w postaci niepodjęcia uchwały o utworzeniu okręgów, ale również w sytuacji, gdy stwierdzi on niezgodność z prawem tej uchwały.

23 Art. 98a u.s.g.: „Jeżeli właściwy organ gminy, wbrew obowiązkowi wynikającemu z przepisów art. 383 § 2 i 6 oraz art. 492 § 2 i 5 ustawy, o której mowa w art. 24b ust. 6, oraz art. 5 ust. 2 i 3 ustawy z dnia 21 sierpnia 1997 r. o ograniczeniu prowadzenia działalności gospodarczej przez osoby pełniące funkcje publiczne, w zakresie dotyczącym odpowiednio wygaśnięcia mandatu radnego, wygaśnięcia mandatu wójta, odwołania ze stanowiska albo rozwiązania umowy o pracę z zastępcą wójta, sekretarzem gminy, skarbnikiem gminy, kierownikiem jednostki organizacyjnej gminy i osobą zarządzającą lub członkiem organu zarządzającego gminną osobą prawną, nie podejmuje uchwały, nie odwołuje ze stanowiska lub nie rozwiązuje umowy o pracę, wojewoda wzywa organ gminy do podjęcia odpowiedniego aktu w terminie 30 dni".

24 Tekst jedn. Dz.U. z 2012 r. poz. 647 z późn. zm.

25 P. Chmielnicki, (w:) K. Bandarzewski, P. Chmielnicki (red.), P. Dobosz, W. Kisiel, M. Kryczko, M. Mączyński, S. Płażek, Komentarz do ustawy o samorządzie gminnym, Warszawa 2007, s. 703.

26 A. Matan, (w:) B. Dolnicki (red.), Ustawa o samorządzie gminnym. Komentarz., Warszawa 2010, s. 914-915. 
Ponadto należy zauważyć, że art. 13 pkt 8a ustawy o ogłaszaniu aktów normatywnych wymaga, aby rozstrzygnięcia nadzorcze dotyczące aktów prawa miejscowego stanowionych przez jednostki samorządu terytorialnego były ogłaszane w wojewódzkim dzienniku urzędowym. $Z$ uwagi na to, że postanowienie zastępcze komisarza wyborczego nie jest aktem nadzoru w ścisłym znaczeniu, to do tego, aby wywoływało skutki prawne, nie jest konieczna jego publikacja.

$\mathrm{Z}$ powyższego wynika, że ustawodawca przyznał komisarzowi wyborczemu swoisty środek nadzoru i tym samym naruszył art. 171 ust. 2 Konstytucji RP. Postanowienie zastępcze narusza samodzielność jst, ponieważ tylko organom nadzoru nad jst ustawodawca może powierzyć kompetencje do władczego ingerowania w samodzielność samorządu terytorialnego.

\section{Kontrola legalności gminnych aktów prawa miejscowego przez sąd administracyjny - uwagi ogólne}

Problematykę związaną z sądową kontrolą aktów prawa miejscowego w sposób ogólny regulują przepisy ustawy z dnia 30 sierpnia 2002 r. - Prawo o postępowaniu przed sądami administracyjnymi, ${ }^{27}$ które są stosowane lub współstosowane ze szczególnymi przepisami procesowymi zawartymi w ustawach ustrojowych. ${ }^{28} \mathrm{Kon}$ trola legalności aktów prawa miejscowego może być bezpośrednia, gdy do sądu zaskarżony jest akt prawa miejscowego i pośrednia, gdy zaskarżony jest akt nadzoru stwierdzający nieważność aktu prawa miejscowego. ${ }^{29}$

Zakresem sądowej kontroli objęte są wszystkie akty prawa miejscowego. ${ }^{30}$ Do podmiotów mających legitymację skargową w odniesieniu do aktów prawa miejscowego należą w szczególności: każdy, czyj interes prawny lub uprawnienie zostały naruszone danym aktem; ${ }^{31}$ wojewodowie, gdy nie skorzystali z możliwości stwierdzenia nieważności aktu prawa miejscowego w trybie nadzoru. ${ }^{32}$

Kompetencje sądu administracyjnego w toku kontroli legalności aktów prawa miejscowego określa na gruncie przepisów p.p.s.a art. 147 i na gruncie u.s.g. art. 94. Przepis art. 147 p.p.s.a w $§ 1$ stanowi, że Sąd uwzględniając skargę na uchwałę lub akt, o których mowa w art. $3 \S 2$ pkt 5 i 6 , stwierdza nieważność tej uchwały lub

Tekst jedn. Dz.U. z 2012 r. poz. 270 z póżn. zm., dalej powoływana jako p.p.s.a.

W przypadku gminnych aktów prawa miejscowego jest to ustawa o samorządzie gminnym.

M. Stahl, Zagadnienia proceduralne sądowej kontroli aktów prawa miejscowego, „Zeszyty Naukowe Sądownictwa Administracyjnego" 2013, nr 3, s. 53.

Art. $3 \S 2$ pkt 5 p.p.s.a.: „Kontrola działalności administracji publicznej przez sądy administracyjne obejmuje orzekanie w sprawach skarg na akty prawa miejscowego organów jednostek samorządu terytorialnego i terenowych organów administracji rządowej”.

Art. 101 ust. 1 u.s.g.: „Każdy, czyj interes prawny lub uprawnienie zostały naruszone uchwałą lub zarządzeniem podjętymi przez organ gminy w sprawie z zakresu administracji publicznej, może - po bezskutecznym wezwaniu do usunięcia naruszenia - zaskarżyć uchwałę do sądu administracyjnego".

Art. 93 ust. 1 u.s.g.: „Po upływie terminu wskazanego w art. 91 ust. 1 organ nadzoru nie może we własnym zakresie stwierdzić nieważności uchwały lub zarządzenia organu gminy. W tym przypadku organ nadzoru może zaskarżyć uchwałę lub zarządzenie do sądu administracyjnego". 
aktu w całości lub w części albo stwierdza, że zostały wydane z naruszeniem prawa, jeżeli przepis szczególny wyłącza stwierdzenie ich nieważności. Zgodnie z przepisem szczególnym - art. 94 ust. 1 i 2 u.s.g. nie stwierdza się nieważności uchwały lub zarządzenia organu gminy po upływie jednego roku od dnia ich podjęcia, chyba że uchybiono obowiązkowi przedłożenia uchwały lub zarządzenia w terminie określonym w art. 90 ust. 1, albo jeżeli są one aktem prawa miejscowego. Ustęp drugi tego artykułu stanowi natomiast, że jeżeli nie stwierdzono nieważności uchwały lub zarządzenia z powodu upływu terminu określonego w ust. 1, a istnieją przesłanki stwierdzenia nieważności, sąd administracyjny orzeka o ich niezgodności z prawem. Uchwała lub zarządzenie tracą moc prawną z dniem orzeczenia o ich niezgodności z prawem. Stwierdzenie nieważności aktów prawa miejscowego nie jest obwarowane terminem, a więc może nastąpić w każdym czasie.

Pośrednia kontrola aktów prawa miejscowego stanowi konsekwencję przyznania samorządowi gminnemu prawa do sądowej ochrony samodzielności. Podstawową prawną formą ochrony tej samodzielności jest uprawnienie organów jednostek samorządu terytorialnego do wniesienia skargi do sądu administracyjnego na działalność organów państwowych sprawujących nadzór nad tym samorządem. Tak zatem art. $3 \S 2$ pkt 7 p.p.s.a dopuszcza skargę do sądu administracyjnego na akty nadzoru nad działalnością organów samorządu terytorialnego. Przepis art. 92a u.s.g. stanowi, że w przypadku złożenia przez organ gminy skargi na rozstrzygnięcie nadzorcze, sąd administracyjny wyznacza rozprawę nie później niż w ciągu 30 dni od dnia wpłynięcia skargi do sądu. Określenie maksymalnego 30-dniowego terminu dla wyznaczenia rozprawy przez sąd administracyjny, na której ma być rozpoznana skarga organu gminy na rozstrzygnięcie nadzorcze, nastąpiło z uwagi na fakt, że w świetle art. 92 ust. 1 u.s.g. doręczenie organowi gminy rozstrzygnięcia nadzorczego stwierdzającego nieważność uchwały lub zarządzenia organu gminy wstrzymuje z mocy prawa wykonanie tej uchwały lub zarządzenia, co z kolei skutkuje niemożnością podjęcia na ich podstawie żadnych działań. Sąd administracyjny, uwzględniając skargę organu jednostki samorządu terytorialnego na akt nadzoru, uchyla ten akt (art. 148 p.p.s.a.). Powołany przepis nie wymienia żadnej przesłanki uchylenia przez sąd zaskarżonego aktu nadzoru. Nie czynią tego także normy wynikające z ustawy ustrojowej. W świetle obowiązującego stanu prawnego stwierdzić należy, że sąd musi uchylić akt nadzoru niezależnie od stopnia naruszenia prawa. Wyłączona jest bowiem możliwość zastosowania sankcji nieważności w stosunku do aktów nadzoru, które mogą być dotknięte kwalifikowanymi wadami. Prawomocny wyrok sądu administracyjnego uwzględniający skargę oddziałuje na zakończone postępowanie nadzorcze w ten sposób, że otwiera możliwość ponownego rozpoznania sprawy i rozstrzygnięcia co do meritum. 


\section{Kontrola legalności uchwały rady gminy w sprawie okręgów wyborczych}

Ustawodawca w k.w. pomimo tego, że uchwała rady gminy w sprawie okręgów wyborczych jest aktem prawa miejscowego, kwestie dotyczące kontroli jej legalności ukształtował w sposób zasadniczo odbiegający od przedstawionych zasad ogólnych.

Na gruncie k.w. bezpośrednią kontrolę legalności sprawowaną przez sądy administracyjne w stosunku do aktów prawa miejscowego zastąpiono szczegółową regulacją zawartą w art. 420 k.w. Na podstawie tej regulacji komisarz wyborczy uzyskał prawo weryfikacji uchwał w sprawie okręgów wyborczych. Tryb ten jest uruchamiany skargą wyborców, w liczbie co najmniej 15, która powinna być wniesiona do komisarza wyborczego w terminie 5 dni od daty podania do publicznej widomości uchwały. Komisarz wyborczy rozpoznaje sprawę w terminie 5 dni i wydaje postanowienie, doręczając je niezwłocznie wnoszącym skargę oraz radzie gminy (art. $420 \S 1$ k.w.). Od postanowienia komisarza wyborczego przysługuje odwołanie do Państwowej Komisji Wyborczej w terminie 5 dni od daty jego doręczenia. Od orzeczenia Państwowej Komisji Wyborczej nie przysługuje środek prawny (art. $420 \S 2$ k.w.).

$\mathrm{Na}$ gruncie tej regulacji w orzecznictwie sądowym przyjmuje się, że tryb zaskarżania uchwał rad gmin w przedmiocie okręgów wyborczych uregulowany został kompleksowo w k.w. Przepis art. 420 k.w. wprowadza szczególny tryb zaskarżania uchwał rady gminy w sprawie okręgów wyborczych. Jego jednoznaczne brzmienie wyłącza właściwość rzeczową sądów administracyjnych w takich sprawach. W konsekwencji w tego typu sprawach nie będzie miał zastosowania art. 101 u.s.g. w zw. z art. $3 \S 2$ pkt 5 p.p.s.a. Skargi wnoszone w tym trybie są odrzucane. ${ }^{33}$ Oznacza to, że na skutek tej regulacji szczególnej faktycznie pozbawiono wyborców drogi sądowej do oceny zgodności z prawem uchwały w przedmiocie okręgów wyborczych. W świetle zasady zaskarżalności do sądu administracyjnego każdego aktu prawa miejscowego, regulację tę należy ocenić jako naruszającą zasadę dostępu do sądu. W miejsce sądu administracyjnego weryfikację takich uchwał powierzono organom administracji wyborczej, wyłączając jednocześnie możliwość zaskarżenia do sądu orzeczenia PKW.

Wbrew temu co podnosi się w orzecznictwie trudno przyjąć, że treść regulacji zawartej w art. 420 k.w. jest jednoznaczna i w sposób wyczerpujący reguluje procedurę wnoszenia skarg w sprawach podziału gminy na okręgi wyborcze. Przede wszystkim, na co już zwrócono uwagę wcześniej, wątpliwości nasuwa treść postanowienia wydawanego przez komisarza wyborczego na skutek skargi. Ustawodawca 
stanowi tylko o tym, że komisarz ,wydaje postanowienie”. W związku z tym należy zadać sobie pytanie, czy sformułowanie „wydaje postanowienie” jest równoznaczne z przyznaniem komisarzowi wyborczemu także i w tym wypadku kompetencji zastępczego podziału gminy na okręgi wyborcze. Czy jest to tylko nazwa formy realizacji przez komisarza wyborczego swoich ustawowych uprawnień. Jeżeli istotnie ustawodawcy chodziłoby o wydanie postanowienia zastępczego to, dlaczego tylko w art. $420 \S 2$ k.w. przewidziano możliwość odwołania od takiego postanowienia do PKW (takiej możliwości nie przewiduje art. $17 \S 2$ k.w.).

Analiza treści uzasadnienia pytania prawnego wskazuje, że NSA zwrot ,wydaje postanowienie" utożsamia z postanowieniem zastępczym, o którym mowa w art. $17 \S 2$ k.w. Wydaje się, że NSA nie zauważa, iż art. $17 \S 2$ k.w. i art. 420 $\S 2$ k.w. regulują dwie różne instytucje (dwie różne kompetencje komisarza wyborczego). W przypadku art. 17 § 2 k.w. komisarz wyborczy działa jako sui genris organ nadzoru, natomiast w przypadku art. $420 \S 2$ k.w. jako organ weryfikujący uchwałę na skutek skargi wyborców.

Kolejna wątpliwość związana jest z tym, że w analizowanym przepisie nie zostały określone materialne przesłanki wniesienia skargi do komisarza wyborczego, co prowadzić może do wniosku, że możliwość zaskarżania uchwał rady gminy w sprawie okręgów wyborczych występuje każdorazowo, bez związku z wątpliwościami co do legalności podjętej przez radę uchwały. Innymi słowy, literalna wykładnia art. $420 \S 1$ k.w. może prowadzić do wniosku, że komisarz uprawniony jest do kontroli podziału gminy na okręgi wyborcze nie tylko pod kątem zgodności z prawem, lecz również z wszelkich innych powodów o charakterze pozaprawnym (np. celowości, efektywności).

Biorąc pod uwagę to, że prawo do sądu, wyrażone w art. 45 ust. 1 Konstytucji, nie może zostać ograniczone w postaci zamknięcia przez ustawę drogi sądowej stwierdzić należy, że przedmiotowa regulacja szczególna nie powinna wyłączać możliwości zaskarżenia uchwał o podziale na okręgi wyborcze na zasadach ogólnych (na podstawie art. 101 u.s.g. w zw. z art. $3 \S 2$ pkt 5 p.p.s.a.). Stąd też odrzucanie skarg, wnoszonych na tej podstawie, przez sądy administracyjne należy ocenić jako wadliwe.

Jeżeli chodzi o pośrednią kontrolę sądu administracyjnego dotyczącą uchwały o podziale gminy na okręgi wyborcze to stwierdzić należy, że kwestia ta uregulowana jest dwutorowo. Ustawodawca regulując w sposób szczególny ,„postępowanie nadzorcze" w k.w. nie wyłączył jednocześnie nadzoru wojewody. Oznacza to, że z jednej strony w stosunku do takiej uchwały toczyć się będzie postępowanie nadzorcze na zasadach ogólnych w trybie przepisów rozdziału 10 u.s.g. Z regulacji tej wynika, że w przypadku sprzeczności z prawem uchwały wojewoda stwierdza jej nieważność - art. 91 ust. 1 u.s.g. Na to rozstrzygnięcie nadzorcze wojewody radzie gminy przysługuje na zasadach ogólnych skarga do sądu administracyjnego - art. 3 $\S 2$ pkt 7 p.p.s.a. Z drugiej strony ustawodawca wyposażył organ administracji wy- 
borczej - komisarza wyborczego w kompetencję do wezwania organów jednostki samorządu terytorialnego do wykonania w terminie, w sposób zgodny z prawem zadań dotyczących podziału gminy na okręgi wyborcze, a następnie do zastępczego podziału gminy na okręgi wyborcze w razie bezskutecznego upływu terminu.

W takiej sytuacji należy zadać pytanie, czy oba tryby postępowania są konkurencyjne czy też będą się uzupełniały. Swoistego rodzaju nadzór sprawowany przez komisarza wyborczego sprowadza się do weryfikacji postępowania gminy. Na skutek działania komisarza wyborczego albo zostaje usunięta bezczynność rady gminy w podziale gminy na okręgi wyborcze, albo zostaje konwalidowana uchwała podjęta w tym zakresie niezgodnie z prawem. Natomiast nadzór wojewody ma charakter kasacyjny, który sprowadza się do wyeliminowania $\mathrm{z}$ obrotu prawnego uchwały sprzecznej z prawem. Wydaje się, że w przypadku, gdy oba organy stwierdzają sprzeczność uchwały z prawem można mówić o uzupełniającym charakterze przedmiotowych trybów postępowania (wojewoda „kasuje” z obrotu prawnego taką uchwałę, a komisarz wyborczy w to miejsce wydaje weryfikacyjne postanowienie zastępcze). Jak wspomniano wcześniej, sytuacja ulega skomplikowaniu wówczas, gdy oba organy dojdą do różnych wniosków, a mianowicie wojewoda nie stwierdzi sprzeczności z prawem uchwały albo stwierdzi nieistotne jego naruszenie (taka uchwała pozostaje w obrocie prawnym), a komisarz wyborczy wyda postanowienie zastępcze. Wówczas w obrocie prawnym będą funkcjonować dwa rozstrzygnięcia o podziale gminy na okręgi wyborcze. W takiej sytuacji pojawia się pytanie dotyczące mocy wiążącej każdego z tych rozstrzygnięć.

Ustawodawca powierzając organowi wyborczemu, nie będącemu sensu stricto organem nadzoru, kompetencje nadzorcze polegające na możliwości zastąpienia rady gminy w podjęciu uchwały o charakterze aktu prawa miejscowego nie zapewnił gminie ochrony sądowej w zakresie jej samodzielności, co należy uznać za naruszenie art. 165 ust. 2 Konstytucji RP. Brak jest regulacji szczególnej, która przewidywałaby możliwość zaskarżenia postanowienia zastępczego komisarza wyborczego do sądu administracyjnego. Przykładowo taką szczególną regulacją na gruncie k.w. jest art. $384 \S 1$. Stanowi on, że „[...] od postanowienia komisarza wyborczego o wygaśnięciu mandatu radnego [...] przysługuje skarga do sądu administracyjnego". Nie wydaje się również, aby taką podstawę mógł stanowić art. $3 \S 2$ pkt 7 p.p.s.a., albowiem postanowienie zastępcze jest swoistego rodzaju rozstrzygnięciem nadzorczym.

\section{Wnioski końcowe}

Analiza pozycji ustrojowej komisarza wyborczego w procesie podziału gminy na okręgi wyborcze do rad gmin wskazuje, że na mocy Kodeksu wyborczego przyznano komisarzowi, który jest przede wszystkim organem wyborczym, sze- 
reg kompetencji zastrzeżonych dla organów administracji publicznej oraz sądów administracyjnych.

Ustawodawca, wprowadzając możliwość wydania postanowienia w trybie art. $17 \S 2$ oraz $420 \S 2$ k.w., miał z pewnością na uwadze specyfikę postępowania wyborczego. Kierował się względami szybkości procedowania oraz zaufaniem do profesjonalnego i apolitycznego przygotowania w zakresie prawa wyborczego organów administracji wyborczej. Jednakże, jak starano się dowieść powyżej, wskazane przepisy budzą poważne wątpliwości co do ich zgodności z Konstytucją RP.

Po pierwsze, przyznają one organowi wyborczemu prawo do stanowienia prawa miejscowego. Wydanie postanowienia na podstawie art. $17 \S 2 \mathrm{k}$.w. zastępuje uchwałę rady gminy w ścisłym znaczeniu, co jest sprzeczne z art. 87 ust. 2 i art. 94 Konstytucji RP. Po drugie, tryb zaskarżania uchwały na mocy art. 420 k.w. co do zasady wyłącza możliwość zaskarżenia uchwały o utworzeniu okręgów wyborczych do sądu administracyjnego na mocy art. 101 u.s.g. i tym samym pozbawia wyborców prawa do sądu przewidzianego w art. 45 ust. 1 Konstytucji RP. Po trzecie wreszcie, przyznają organowi wyborczemu nadzór nad jst i upoważniają go do stanowienia prawa miejscowego, pozbawiając jednocześnie gminę możliwości zaskarżenia do sądu administracyjnego postanowienia zastępczego komisarza wyborczego. Takie rozwiązanie stanowi naruszenie zagwarantowanej w art. 165 Konstytucji RP sądowej ochrony samodzielności samorządu terytorialnego.

Komisarz wyborczy w procesie tworzenia okręgów wyborczych do rad gmin powinien stać na straży prawidłowego przebiegu tego procesu, ale w żadnym wypadku nie może władczo ingerować w działalność samorządu terytorialnego. Zasadnym wydaje się więc sformułowanie następujących wniosków de lege ferenda. Po pierwsze, komisarz wyborczy zamiast wydawać postanowienie zastępcze powinien, podobnie jak na gruncie Ordynacji wyborczej z dnia 16 lipca 1998 r., zwracać się z wnioskiem do wojewody o wydanie odpowiedniego aktu. Po drugie, wyborcy muszą mieć zagwarantowane prawo do sądu i możliwość zaskarżenia każdego aktu prawa miejscowego bez względu na jego przedmiot. Tylko tak ukształtowany proces wyborczy będzie odpowiadał standardom demokratycznego państwa prawnego.

\section{BIBLIOGRAFIA}

Brzeski M., Problemy kontroli sądowo administracyjnej działalności prawotwórczej podmiotów samorządu terytorialnego niebędących organami tego samorządu, (w:) B. Dolnicki, J.P. Tarno (red.), Samorząd terytorialny a Polsce a sądowa kontrola administracji, Warszawa 2012

Chmielnicki P., (w:) K. Bandarzewski P. Chmielnicki (red.), P. Dobosz, W. Kisiel, M. Kryczko, M. Mączyński, S. Płażek, Komentarz do ustawy o samorządzie gminnym, Warszawa 2007

Dąbek D., Prawo miejscowe, Warszawa 2007

Dąbek D., Sądowa kontrola aktów prawa miejscowego - aspekt materialno-prawny, Zeszyty Naukowe Sądownictwa Administracyjnego 2013, nr 3 
Dobosz P., (w:) K. Bandarzewski, P. Chmielnicki, P. dobosz. W. Kisiel. P. Pryczko. M. Mączyński, Komentarz do ustawy o samorządzie gminnym, Warszawa 2004

Jagoda J., Sądowa ochrona samodzielności jednostek samorządu terytorialnego, Warszawa 2011

Matan A., (w:) B. Dolnicki (red.), Ustawa o samorządzie gminnym. Komentarz., Warszawa 2010

Moll T., (w:) B. Dolnicki (red.), Ustawa o samorządzie gminnym. Komentarz, Warszawa 2010

Stahl M., Zagadnienia proceduralne sądowej kontroli aktów prawa miejscowego, "Zeszyty Naukowe Sądownictwa Administracyjnego" 2013, nr 3 


\section{THE ROLE OF THE ELECTORAL COMMISSIONER IN THE DIVISION OF MUNICIPALITIES INTO CONSTITUENCIES}

The subject of this article is to analyze the role of the electoral commissioner in the process of creating constituencies for municipal elections. It presents the evolution of the position of the electoral commissioner with the focus on his functions in relation to the creation of constituencies by the municipality. The paper shows the legal nature of a resolution of the municipal council concerning the creation of constituencies and also of a replacement order issued by the electoral commissioner. In addition, the article discusses the problem of supervision and control of a resolution of the municipal council about creation of constituencies for the local elections. The main aim of the article is to show that the competence of the commissioner to issue a replacement order infringes Article 87 paragraph 2 of the Polish Constitution, because it grants him the right to enact local laws, and because the lack of possibility to file a complaint within the administrative court for the resolution on creation of constituencies is at variance with Article 45 paragraph 1 of the Polish Constitution.

Keywords: electoral commissioner, constituencies, replacement order

Słowa kluczowe: komisarz wyborczy, okręgi wyborcze, postanowienie zastępcze 